\title{
Feeding by the mixotrophic thecate dinoflagellate Fragilidium cf. mexicanum on red-tide and toxic dinoflagellates
}

\author{
Hae Jin Jeong ${ }^{1, *}$, Jae Hyung Shim ${ }^{2}$, Jae Seong Kim ${ }^{1}$, Jae Yeon Park ${ }^{2}$, \\ Chang Won Lee ${ }^{1}$, Yoon Lee ${ }^{3}$ \\ ${ }^{1}$ Department of Oceanography, College of Natural Sciences, Kunsan National University, Kunsan 573-701, Republic of Korea \\ ${ }^{2}$ The Research Institute of Oceanography, Seoul National University, Seoul 151-742, Republic of Korea \\ ${ }^{3}$ National Fisheries Research and Development Agency, Inchon 400-201, Republic of Korea
}

\begin{abstract}
We investigated prey species, prey selectivity, growth rates, grazing rates, and the effect of light and nutrient environment on feeding for the thecate mixotrophic dinoflagellate Fragilidium cf. mexicanum. Among the red-tide and toxic dinoflagellate prey offered, Lingulodinium polyedrum, Gymnodinium sanguineum, Prorocentrum micans, P. minimum, and Scnppsiella trochoidea were ingested by $F$. cf. mexicamum, but Amphidinium carterae and Cochlodinium polykrikoides were not. The feeding frequency $(\mathrm{FF})$, based on the percent of $F$. cf. mexicanum containing one or more target prey cells, was significantly affected by prey species. The maximum FFs of $F$. cf. mexicanum on $L$. polyedrum and $S$. trochoidea after $72 \mathrm{~h}$ incubation in a unialgal diet (50 and $89 \%$, respectively) were much higher than those for $P$. micans, $P$. minimum, and $G$. sanguineum $(6,10$, and $2 \%$, respectively). FFs on $L$. polyedrum and $S$. trochoidea were significantly affected by prey concentration, but those on $P$. micans and $G$. sanguineum were not. F. cf. mexicanum strongly selected $L$. polyedrum over $S$. trochoidea in prey mixtures. With increasing mean prey concentration, growth and ingestion rates of $F$. cf. mexicanum feeding on $L$. polyedrum increased, with saturation at a mean prey concentration of approximately 500 cells $\mathrm{ml}^{-1}$. The maximum specific growth rate (mixotrophic growth) of $F$. cf. mexi-

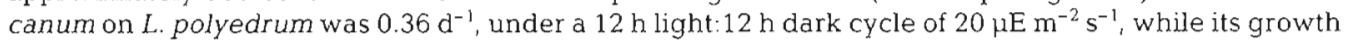
rate (phototrophic growth) under the same light conditions without added prey was $-0.05 \mathrm{~d}^{-1}$ The maximum ingestion rate of $F$. cf. mexicanum on L. polyedrum, 3.9 prey eaten predator ${ }^{-1} \mathrm{~d}^{-1}$, was comparable to those of the co-occurring heterotrophic dinoflagellates Protoperidinium cf. divergens and $P$. crassipes for the same prey. However, maximum clearance rate of $F$. cf. mexicanum, $6 \mu$ l predator ${ }^{-1}$ $\mathrm{h}^{-1}$, was much higher than those of $P$. cf. divergens and $P$. crassipes. The ingestion rate of $F$. cf. mexicanum on $L$. polyedrum was not significantly affected by light intensity or nutrient concentration when prey was plentiful.
\end{abstract}

KEY WORDS: Dinoflagellate Growth Grazing $\cdot$ Mixotrophy Protist Red tide

\section{INTRODUCTION}

Red tides, which consist of dense algal blooms visible at the sea surface, can upset the balance of food webs and cause large-scale mortalities in fish and shellfish (e.g. Norris \& Chew 1975). Studies of red-tide formation and persistence suggest that grazing pressure may sometimes play an important role in red-tide dynamics

•E-mail: hjjeong@ks.kunsan.ac.kr (e.g. Watras et al. 1985). Grazing by microzooplankton such as rotifers, tintinnids, and heterotrophic or mixotrophic dinoflagellates is believed to contribute to the decline of blooms (Holmes et al. 1967, Eppley \& Harrison 1975). A few studies have examined feeding by mixotrophic dinoflagellates on red-tide dinoflagellates (Jacobson \& Anderson 1996, Skovgaard 1996a, b, Hansen \& Nielsen 1997), while many studies have considered feeding by other microzooplanktonic grazers (Eppley \& Harrison 1975, Stoecker et al. 1981, Watras et al. 1985, Jeong \& Latz 1994). Recently, interest in 
phagotrophic feeding by phototrophic dinoflagellates and factors affecting their feeding has increased (Bockstahler \& Coats 1993, Li et al. 1996, Granéli et al 1997, Stoecker et al. 1997).

Species of the mixotrophic dinoflagellate genus Fragilidium have been found in coastal waters off many areas (Balech \& Ferrando 1964, Eppley \& Harrison 1975, Balech 1988, 1990, Skovgaard 1996a, Jeong et al. 1997). Several studies have reported that Fragilidium spp. fed intensively on some red-tide dinoflagellates, especially at the decline of blooms. For example, F. heterolobum was abundant and observed to feed intensively on Lingulodinium polyedrum (Stein) Dodge (previously Gonyaulax polyedra) during red tides (Balech \& Ferrando 1964, Eppley \& Harrison 1975). Similarly F. mexicanum was reported to feed heavily on Alexandrium sp. (Balech 1988). Phagotrophic feeding by $F$. fissle has not been observed yet, but this species might teed on red-tide dinoflagellates since it is sometimes abundant during blooms dominated by Lingulodinium polyedrum and Alexandrium sp. (Balech 1990). While these studies imply rapid feeding and growth of Fragilidium spp. during red tides of $L$. polyedrum and Alexandrium sp., few data are available to test this hypothesis.

Recently, Skovgaard (1996a) described the feeding process of Fragilidium subglobosum, a species which feeds exclusively on Ceratium spp., when offered diverse dinoflagellates and diatoms as prey. A subsequent report quantified growth and grazing rates of F. subglobosum when the feeding was on Ceratium spp. (Skovgaard 1996b, Hansen \& Nielsen 1997). Other Fragilidium species may have different prey and varying degrees of selectivity. However, there are no reports on the feeding of Fragilidium species on other dinoflagellates that frequently form red tides. Therefore, to investigate the role of Fragilidium species in redtide dynamics, it is important to quantify growth and grazing rates of Fragilidium species on red-tide dinoflagellates and to explore prey species and prey selectivity.

Feeding of some mixotrophic nanoflagellates and dinoflagellates is known to be affected by light intensity and/or nutrient concentrations (Keller et al. 1994, Skovgaard 1996b, Hansen \& Nielsen 1997, Stoecker et al. 1997). However, feeding of a few mixotrophic flagellates appears unaffected by light and nutrient environments if prey are abundant (Sanders et al. 1990). Ingestion of Ceratium spp. by Fragilidium subglobosum was recently found to be affected by light intensity even when prey was plentiful (Skovgaard 1996b, Hansen \& Nielsen 1997). However, no studies have considered the influence of nutrients on feeding of Fragilidium spp. Thus, it is worthwhile to explore the effects of light and nutrient on feeding by Fragilidium spp. on red-tide dinoflagellates.

The present study explores prey species, prey selectivity, grazing rate, growth rate, and the effects of light and nutrients on feeding for the mixotrophic thecate dinoflagellate Fragilidium of. mexicanum when presented red-tide or toxic dinoflagellates as prey. Prey species included the most frequently encountered red-tide dinoflagellates of coastal waters off southern California where $F$. cf. mexicanum was isolated. Amphidinium carterae has not been reported to cause red tides, but it is toxic (Steidinger \& Tangen 1996). Growth and ingestion rates of $F$. cf. mexicanum on Lingulodinium polyedrum under conditions that did not support phototrophic growth of the grazer were compared to those of Protoperidinium cf. divergens and $P$. crassipes, heterotrophic dinoflagellates that cooccur with F. cf. mexicanum (Jeong \& Latz 1994). The results of the present study provide a basis for understanding the interactions between $F$. cf. mexicanum and red-tide or toxic dinoflagellates.

\section{MATERIALS AND METHODS}

Culture of phytoplankton prey. Seven dinoflagellate prey species (Table 1) were cultured in enriched $\mathrm{f} / 2$ seawater medium (Guillard \& Ryther 1962) without silicate and maintained at $22^{\circ} \mathrm{C}$ with continuous illumination of $100 \mu \mathrm{E} \mathrm{m}^{-2} \mathrm{~s}^{-1}$ supplied by cool white fluores-
Table 1. Autotrophic (auto) and mixotrophic (mixo) species used in the present study listed in order of size. Mean equivalent spherical diameter (ESD) $\pm \mathrm{SD}$ of the mean was measured by the PAMAS-SVSS particle counter. Volume (to the nearest hundred) was calculated according to the equation: volume $=4 / 3 \pi(\mathrm{ESD} / 2)^{3}$ The number of cells measured was $>2000$

\begin{tabular}{|c|c|c|c|}
\hline Species & ESD $(\mu \mathrm{m})$ & $\begin{array}{l}\text { Approximate } \\
\text { volume }\left(\mu m^{3}\right)\end{array}$ & $\begin{array}{l}\text { Trophic } \\
\text { mode }\end{array}$ \\
\hline \multicolumn{4}{|l|}{ Prey } \\
\hline Prorocentrum minimum & $12.9 \pm 3.6$ & 1100 & Mixob \\
\hline Amphidinium carterae & $16.2 \pm 2.5$ & 2200 & $\mathrm{Mixo}^{\mathrm{c}}$ \\
\hline Cochlodinium polykrikoides & $23.2 \pm 3.1$ & 6600 & Auto \\
\hline Scrippsiella trochoidea & $25.1 \pm 2.8$ & 8300 & Mixo $^{d}$ \\
\hline Prorocentrum micans & $26.0 \pm 2.3$ & 9200 & Mixo ${ }^{d}$ \\
\hline Gymnodinium sanguineum & $36.3 \pm 5.6$ & 25000 & Mixo ${ }^{e}$ \\
\hline Lingulodinium polyedrum & $37.9 \pm 4.5$ & 28500 & Auto \\
\hline \multicolumn{4}{|l|}{ Predator } \\
\hline Fragilidium cf. mexicanum & $54.5 \pm 8.7^{\grave{a}}$ & 84600 & Mixo \\
\hline \multicolumn{4}{|c|}{ 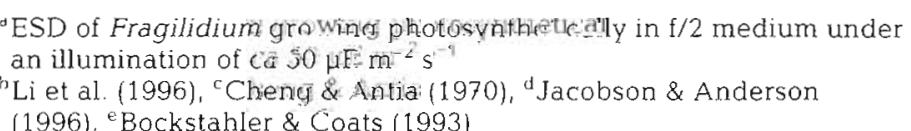 } \\
\hline
\end{tabular}


cent lights. Cultures in exponential growth phase were used for all feeding experiments except the nutrient effect experiment, for which cultures in stationary growth phase were used see 'Nutrient effects on feeding'). Carbon contents for dinoflagellates were estimated from cell volume according to Strathmann (1967).

Isolation and culture of Fragilidium cf. mexicanum. Plankton samples were taken at the end of the Scripps pier (La Jolla, CA, USA) during May, 1996, using a $35 \mathrm{~cm}$ diameter, $25 \mu \mathrm{m}$ mesh plankton net and gently screened through $100 \mu \mathrm{m}$ Nitex mesh before being placed in $150 \mathrm{ml}$ plastic bottles for shipment to Korea. Detailed methods for culturing Fragilidium cf. mexicanum are described by Jeong et al. (1997).

Prey species and concentration effects. Seven experiments ( 1 to 7 , sequentially) were designed to investigate the effects of prey species and prey concentration on feeding by Fragilidium cf. mexicanum. Feeding frequencies (FFs) of F. cf. mexicanum on prey after $2 \mathrm{~h}$ and $72 \mathrm{~h}$ incubation, rather than ingestion rates, were compared because ingestion rates for some prey species in preliminary experiments were too low to be measure reliably (e.g. the maximum ingestion rates of F. cf. mexicanum on Gymnodinium sanguineum and Prorocentrum micans were only 0.2 and 0.7 prey eaten predator ${ }^{-1} \mathrm{~d}^{-1}$, respectively). FF is the proportion of $F$. cf. mexicanum cells that feed, as determined from the presence of ingested prey, and was calculated as the percentage of $F$. cf. mexicanum containing 1 or more target prey cells. FFs after $2 \mathrm{~h}$ show the relative ease of capture and/or ingestion of target prey by $F$. cf. mexicanum when unialgal diets were provided.

Lingulodinium polyedrum and Scrippsiella trochoidea cells were easily observed in the cytoplasm of Fragilidium cf. mexicanum for at least $2 \mathrm{~h}$ after being ingested. Thus, the number of prey observed in the cytoplasm of $F$. cf. mexicanum after $2 \mathrm{~h}$ of feeding represents the total number ingested only when $L$. polyedrum and $S$. trochoidea were used as prey. FFs after $72 \mathrm{~h}$ incubation show whether or not $F$. cf. mexicanum were able to feed on the target prey species, but cannot be used to calculate feeding rate. FFs as a function of prey concentration in a unialgal diet provide some insight on the effect of prey concentration on the grazer's feeding, while the average number of ingested target prey observed inside the grazer (APN) reveals whether or not a second and/or later target prey cell is attacked before the first is digested completely.

Eight hundred $\mathrm{ml}$ of a dense culture of Fragilidium cf. mexicanum maintained in $\mathrm{f} / 2$ media and growing photosynthetically on shelves illuminated with $50 \mu \mathrm{E}$ $\mathrm{m}^{-2} \mathrm{~s}^{-1}$ of cool white fluorescent light on a $12 \mathrm{~h}$ light: $12 \mathrm{~h}$ dark cycle was transferred to a $1 \mathrm{l}$ polycarbonate (PC) bottle containing approximately $200 \mathrm{ml}$ freshly filtered seawater. Three $1 \mathrm{ml}$ aliquots were then removed from the bottle and examined using a compound microscope to determine $F$. cf. mexicanum concentration. The diluted culture in the 11 bottle was then used to set up an experiment.

In all experiments, the initial concentrations of Fragilidium cf. mexicanum and prey were established using an autopipette to deliver a predetermined volume of culture with known cell density to the experimental bottles. Six $32 \mathrm{ml} \mathrm{PC}$ bottles (mixtures of predator and prey) and duplicate $32 \mathrm{ml} \mathrm{PC} \mathrm{control} \mathrm{bottles} \mathrm{containing}$ only $F$. cf. mexicanum were set up for each predatorprey treatment. Three $\mathrm{ml}$ of $\mathrm{t} / 2$ medium were added to all bottles, which were then filled to capacity with freshly filtered seawater. Initial concentrations of predators and prey were determined for each bottle by enumerating cells present in three $1 \mathrm{ml}$ aliquots. The bottles were again filled to capacity with freshly filtered seawater, capped, and placed on a rotating wheel at $0.9 \mathrm{rpm}$ at $22^{\circ} \mathrm{C}$, where they received cool white fluorescent light on a 12 h light: 12 h dark cycle. Bottles were illuminated from above, with light intensity $\left(20 \mu \mathrm{E} \mathrm{m}^{-2} \mathrm{~s}^{-1}\right)$ calculated as the mean of measurements made using a light sensor (LI-COR LI-1000 DataLogger) placed inside a bottle hanging on the top

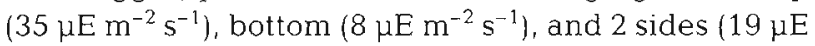
$\mathrm{m}^{-2} \mathrm{~s}^{-1}$ ) of the rotating wheel.

All bottles were taken from the rotating wheel at 2 , 24,48 , and 72 h to observe interactions between Fragilidium cf. mexicanum and its prey. Observations were made with a dissecting microscope, which was used to look through the surfaces of the bottles without removing the caps. The contents of 1 set of triplicate experimental bottles were fixed at $2 \mathrm{~h}$ for each treatment. while those of the experimental bottles and the control bottles were preserved at $72 \mathrm{~h}$. Samples were fixed with either glutaraldehyde (for Gymnodinium sanguineum prey) or Bouin's solution (for Lingulodinium polyedrum, Scrippsiella trochoidea, Prorocentrum micans, and $P$. minimum prey), depending on prey species and results of preliminary experiments to determine which fixative provided the best visibility of prey species inside the protoplasm of the grazer. Cells were counted within 2 d after preservation because $F$. cf. mexicanum cells gradually turned dark even when glutaraldehyde was used as the fixative. The number of prey cells observed inside $F$. cf. mexicanum (i.e. ingested prey) and in the medium and the numbers of $F$. cf. mexicanum with and without ingested prey were determined by observing and counting all or $>300$ cells in three to seven $1 \mathrm{ml}$ Sedgwick-Rafter chambers using a compound microscope.

Pre-ingestion processes. In Expts 1 to 7, FFs were significantly affected by prey species. To investigate the cause for this difference in FFs, the pre-ingestion 
process of Fragilidium cf. mexicanum was observed and video recorded for each prey species following the addition of dense predator and prey to 6 -well plate chambers ( $3.5 \mathrm{~cm}$ in diameter and $18 \mathrm{ml}$ in volume). Video recordings were taken at 10 to $100 \times$ using Olympus compound and dissecting microscopes equipped with a Watec video camera (Wat 202B).

Swimming speed. In the observation of pre-ingestion processes, we found that Fragilidium cf. mexicanum could not capture fast-swimming Cochlodinium polykrikoides. Thus, swimming speeds of prey and F. cf. mexicanum were measured at $22^{\circ} \mathrm{C}$ using a video analyzing system. For each species, aliquots from a dense culture were added to multiwell plates and allowed to acclimate for $30 \mathrm{~min}$. Swimming was then observed and recorded at $40 \times$ as described above, with mean and maximum swimming velocity analyzed for fast-swimming cells that exhibited straight linear paths. Average swimming speed was calculated based on the linear displacement of cells in $1 \mathrm{~s}$ during singleframe playback. Swimming speeds of more than 10 cells were measured for each dinoflagellate species.

Growth and ingestion of Fragilidium cf. mexicanum. Expts 8 and 9 were designed to measure growth, ingestion, and clearance rates of Fragilidium cf. mexicanum feeding on Lingulodinium polyedrum as a function of the prey concentration (Table 2). About 1 or $2 \mathrm{~d}$ before these experiments were conducted, dense cultures of $F$. cf. mexicanum photosynthetically growing in $\mathrm{f} / 2$ medium under an illumination of $50 \mu \mathrm{E}$ $\mathrm{m}^{-2} \mathrm{~s}^{-1}$ of cool white fluorescent light on a $12 \mathrm{~h}$ light: 12 $\mathrm{h}$ dark cycle on shelves were transferred to $1 \mathrm{l} \mathrm{PC}$ bottles containing low concentrations of $L$. polyedrum (approximately 5 cells $\mathrm{ml}^{-1}$ ). The bottles were filled to capacity with filtered seawater and placed on a rotating wheel at 0.9 rpm under a $12 \mathrm{~h}$ light: $12 \mathrm{~h}$ dark cycle of illumination with $20 \mu \mathrm{E} \mathrm{m}^{-2} \mathrm{~s}^{-1}$ of cool white fluorescent light at $22^{\circ} \mathrm{C}$ to acclimate. Bottles were taken from the rotating wheel at intervals and examined under a dissecting microscope to determine the condition of $F$. cf. mexicanum and L. polyedrum, and then placed back on the rotating wheels. Once $L$. polyedrum cells were no longer detectable, three $1 \mathrm{ml}$ aliquots from each bottle were counted using a compound microscope to determine cell concentrations of $F$. cf. mexicanum, and the cultures were then used to conduct experiments.

Initial concentrations of Fragilidium cf. mexicanum and prey were established using an autopipette, with triplicate $270 \mathrm{ml} P C$ experiment bottles (mixtures of predator and prey) set up for each predator-prey concentration. In addition, triplicate control bottles for prey (Lingulodinium polyedrum) and duplicate control bottles for the predator ( $F$. cf. mexicanum) were established at concentrations equal to those in predatorprey combinations. Thirty $\mathrm{ml}$ of $\mathrm{f} / 2$ medium were added to all bottles, which were then filled to capacity with freshly filtered seawater and capped.

Experimental and control bottles were incubated for 3 or $4 \mathrm{~d}$ using a rotating wheel and a mean light intensity of $20 \mu \mathrm{E} \mathrm{m}^{-2} \mathrm{~s}^{-1}$, as previously described. We chose this light intensity to compare growth and ingestion rates of Fragilidium cf. mexicanum on Lingulodinium polyedrum with those of the heterotrophic dinoflagellates Protoperidinium cf. divergens and $P$. crassipes because it did not support photogrowth of $F$. cf. mexicanum, but did keep the prey L. polyedrum in a healthy condition. During preliminary experiments, $L$. polyedrum became unhealthy at light intensities $\leq 10 \mu \mathrm{E} \mathrm{m}^{-2} \mathrm{~s}^{-1}$.

Ten $\mathrm{ml}$ aliquots were taken daily from each bottle and fixed with acidic Lugol's solution. Before taking subsamples, the condition and interaction of Fragilidium cf. mexicanum and Lingulodinium polyedrum were determined by carefully examining the contents of each bottle using a dissecting microscope. After sub-

Table 2. Experimental design. Density values indicate the actual initial concentrations (cells $\mathrm{ml}^{-1}$ ) of prey and predator $\left(F_{r a g j-}\right.$ lidium cf. mexicanum)

\begin{tabular}{|llll|}
\hline Expt & Prey species & Prey density & F. cf. mexicanum density \\
\hline 1 & Lingulodinium polyedrum & $30,120,300,1020,2100$ & $9,20,40,70,115$ \\
2 & Gymnodinium sanguineum & $20,90,280,1100,1960$ & $12,20,44,70,90$ \\
3 & Prorocentrum micans & $27,90,250,1160,2160$ & $15,20,30,60,90$ \\
4 & Scrippsiella trochoidea & $80,490,3350,9130,11850$ & $18,50,100,170,270$ \\
5 & Cochlodinium polykrikoides & $10,90,620,2600,9100$ & $13,30,50,90,120$ \\
6 & Amphidinium carterae & $1360,4630,15500,59400,110600$ & $11,25,50,80,110$ \\
7 & Prorocentrum minimum & $1280,4120,12300,49000,90000$ & $13,25,35,88,120$ \\
8 & L. polyedrum & $5,10,32,63,122$ & $0.8,1.6,2.5,4,9$ \\
9 & L. polyedrum & $46,90,270,740,1400,2230$ & $7,15,24,37,60,103$ \\
10 & L.polyedrum/S, trochoidea & $230 / 2830,520 / 1880,700 / 1470,1180 / 720$ & $56-67$ \\
11 & L.polyedrum & $1710-1770$ & $74-80$ \\
12 & L. polyedrum & $1390-1480$ & $57-64$ \\
\hline
\end{tabular}


samples were taken, bottles were again filled to capacity with freshly filtered seawater and placed back on the rotating wheel. The refilling diluted the cultures in the bottles, which was considered in calculating growth and ingestion rates. The concentrations of $F$. cf. mexicanum and L. polyedrum were determined for fixed samples as previously described.

The specific growth rate of Fragilidium cf. mexicanum $\left(\mathrm{d}^{-1}\right)$ was calculated by averaging the instantaneous growth rates (IGR), which were calculated as

$$
\text { IGR }=\ln \left(F_{t 1} / F_{10}\right)
$$

where $F_{t 0}=$ the concentration of $F$. cf. mexicanum at Day $t_{0}$, and $F_{11}=$ the concentrations at Day $t_{1}$ (next day). The final day for this calculation was Day 3. Ingestion rates were calculated using the equations of Frost (1972) and Heinbokel (1978). Growth yield, defined as grazer biomass produced per prey biomass ingested, was calculated using Hansen \& Nielsen's (1997) equations.

Prey selectivity in prey mixtures. Prey selectivity of Fragilidium cf. mexicanum was examined using mixtures of Lingulodinium polyedrum and Scrippsiella trochoidea as food. F. cf. mexicanum was observed to feed on both prey species when these unialgal diets were offered in Expts 1 and 4. F. cf. mexicanum cells growing photosynthetically in $\mathrm{f} / 2$ medium were added to $32 \mathrm{ml} \mathrm{PC}$ bottles containing different ratios of $L$. polyedrum and $S$. trochoidea (Expt 10 in Table 2). Five experimental bottles (containing both predator and prey) and 4 control bottles (containing only prey) were set up for each predator-prey treatment. Three $\mathrm{ml}$ of $\mathrm{f} / 2$ medium were added to each bottle. The contents of 1 experimental bottle and 1 control bottle were fixed with Lugol's solution to determine the actual initial concentrations of the predator and prey. The remaining bottles were incubated for $2 \mathrm{~d}$ using a rotating wheel and an illumination of $20 \mu \mathrm{E} \mathrm{m}^{-2} \mathrm{~s}^{-1}$, as previously described. After incubation, the contents of each bottle were fixed with acidic Lugol's solution, with predator and/or prey concentrations and predator ingestion rates determined as previously described. The carbon ratio for ingestion rate of $F$. cf. mexicanum on L. polyedrum to that for total prey ( $L$. polyedrum $+S$. trochoidea) was expressed as a function of prey availability ( $L$. polyedrum carbon / total prey carbon).

Light effect on feeding. Expt 11 (Table 2) was conducted to investigate the effect of light intensity on the ingestion rates of Fragilidium cf. mexicanum when offered Lingulodinium polyedrum as prey. Dense cultures of $F$. cf. mexicanum growing mixotrophically on L. polyedrum in f/2 medium and under a $12 \mathrm{~h}$ light: 12 $\mathrm{h}$ dark cycle of cool white fluorescent light at $50 \mu \mathrm{E} \mathrm{\textrm {m } ^ { - 2 }}$ $\mathrm{s}^{-1}$ were transferred to five $1 \mathrm{l} \mathrm{PC}$ bottles containing $L$. polyedrum in f/2 medium (ca 500 cells $\mathrm{ml}^{-1}$ ). Bottles were wrapped with either $8,4,2$, or 1 layer of screening to provide $20,60,100$, and $200 \mu \mathrm{E} \mathrm{m}^{-2} \mathrm{~s}^{-1}$, respectively. The bottles were placed on a vertically rotating plate, maintained at $22 \pm 1^{\circ} \mathrm{C}$, and evenly illuminated from one direction. Target light intensities, as determined inside the bottles, showed little variation during rotation of the plate.

Every 1 or $2 \mathrm{~d}$ the contents of each bottle were evenly divided into two $1 \mathrm{l}$ PC bottles containing $\mathrm{f} / 2$ medium and Lingulodinium polyedrum at ca 500 cells $\mathrm{ml}^{-1}$ and placed back on the rotating plate. In this manner, Fragilidium of. mexicanum cells were acclimated to target light intensities for $8 \mathrm{~d}$. After acclimation, and once L. polyedrum cells were no longer detectable in the bottles, three $1 \mathrm{ml}$ aliquots from each bottle were counted using a compound microscope to determine $F$. cf. mexicanum abundance. Aliquots from each bottle were then transferred to five $32 \mathrm{ml} P C$ bottles containing L. polyedrum. Four $32 \mathrm{ml} P C$ control bottles containing only $L$. polyedrum and another four $32 \mathrm{ml}$ PC control bottles containing only $F$. cf. mexicanum were set up at each light intensity. Sixteen ml of $\mathrm{f} / 2$ medium was added to each PC bottle. The contents of 1 of the experimental bottles and 1 of each set of control bottles at each target light intensity were fixed with Lugol's solution to determine the initial concentrations of predator and/or prey.

Experimental and control bottles were incubated for $2 \mathrm{~d}$ using the vertically rotating plate and target illumination. After incubation, the contents from each bottle were fixed with Lugol's solution. The concentrations of Fragilidium cf. mexicanum and Lingulodinium polyedrum were determined by counting all grazers and $>300$ L. polyedrum cells in three $1 \mathrm{ml}$ Sedgwick-Rafter chambers. Ingestion rates were calculated as previously described.

Nutrient effects on feeding. Expt 12 (Table 2) was conducted to investigate the effects of nutrient concentration on ingestion rate of Fragilidium cf. mexicanum when offered Lingulodinium polyedrum as prey. Dense cultures of $F$. cf. mexicanum growing mixotrophically on $L$. polyedrum were sieved through a $35 \mu \mathrm{m}$ mesh. Cells retained on the sieve were transferred to $1 \mathrm{l} \mathrm{PC}$ bottles containing only oceanic seawater (nitrate + nitrite [hereafter $N$ ] and phosphate $[\mathrm{P}]$ concentrations $<0.1 \mu \mathrm{M}$ ) and placed on an illuminated shelf. After $2 \mathrm{~h}$, fluid from the upper third of the bottle was gently removed and distributed to five 11 PC bottles containing $500 \mathrm{ml}$ of either freshly filtered oceanic seawater (OC), f/2 medium (F), $500 \mathrm{ml} / 2$ medium without $N(F-N), f / 2$ medium without $P(F-P)$, or $f / 2$ medium without both $N$ and $P(F-N-P)$. The bottles were then filled to capacity with freshly filtered oceanic seawater, capped, and placed on a vertically rotating wheel $10.9 \mathrm{rpm} ; 100 \mu \mathrm{E} \mathrm{m}^{-2} \mathrm{~s}^{-1}, 12 \mathrm{~h}$ light: $12 \mathrm{~h}$ 
dark cycle; $22 \pm 1^{\circ} \mathrm{C}$ ). Dense cultures of $L$. polyedrum were also concentrated on $35 \mu \mathrm{m}$ mesh screening and transferred to two 2 I PC bottles containing oceanic water.

Every day thereafter, subsamples were taken from each bottle, gently filtered through GF/F filters, and stored frozen at $-20^{\circ} \mathrm{C}$ until $\mathrm{N}$ and $\mathrm{P}$ concentrations were measured using a Nutrient AutoAnalyzing System (Bran and Luebbe Traacs 2000). After $5 \mathrm{~d}, \mathrm{~N}$ concentrations in bottles containing Fragilidium cf. mexicanum plus $O C, F-N$, or $F-N-P$ were $<1 \mu M$, while $\mathrm{P}$ concentrations in bottles containing $F$. cf. mexicanum plus $O C, F-P$, or $F-N-P$ were $<0.3 \mu \mathrm{M}$. N and $\mathrm{P}$ concentrations in the bottles containing only Lingulodinium polyedrum cells also dropped to $<1$ and $<0.3 \mu \mathrm{M}$, respectively, within $5 \mathrm{~d}$.

These very low $\mathrm{N}$ and $\mathrm{P}$ cultures of Lingulodinium polyedrum (ca 500 cells $\mathrm{ml}^{-1}$; hereafter $L p L N P$ ) were used to feed the $O C, F, F-N$, and $F-N-P$ cultures of Fragilidium of. mexicanum during an additional $6 \mathrm{~d}$ acclimation period. Feeding was done at 1 to $2 \mathrm{~d}$ intervals by transferring the contents of each $F$. cf. mexicanum culture bottle to 2 new $11 \mathrm{PC}$ bottles containing target nutrients and $L p L N P$. During this acclimation period, subsamples were taken daily for determination of $\mathrm{N}$ and $\mathrm{P}$ concentrations. Ranges ( $\mathrm{nd}=$ not detectable) for $N$ (and P) concentrations were $0.08-0.36 \mu \mathrm{M}$ $\mathrm{N}(0.08-0.26 \mu \mathrm{M} \mathrm{P})$ for the $\mathrm{OC}$ bottle, nd-0.09 $\mu \mathrm{MN}$ $(0.06-0.22 \mu \mathrm{M} P)$ in the $F-N-P$ bottle, nd $\mu M N$ (12-38 $\mu \mathrm{M} P$ ) in the $\mathrm{F}-\mathrm{N}$ bottle, 102-247 $\mu \mathrm{M} \mathrm{N}$ (nd $\mu \mathrm{MP}$ ) in the $F-P$ bottle, and 137-243 $\mu \mathrm{M} \mathrm{N}$ $(12-32 \mu \mathrm{M} P)$ in the $F$ bottle.

After acclimation and once Lingulodinium polyedrum cells were no longer detectable, three $1 \mathrm{ml}$ aliquots from each bottle were counted to determine cell concentrations of Fragilidium cf. mexicanum. Aliquots $(2$ to $3 \mathrm{ml}$ ) from each bottle containing acclimated $F$. cf. mexicanum cells were transferred to six $32 \mathrm{ml} \mathrm{PC}$ bottles containing LpLNP (Ca $6 \mathrm{ml}$ ) and $16 \mathrm{ml}$ of matching target nutrients or oceanic water. One set of 4 control bottles containing only LpLNP and another set of 4 control bottles containing only acclimated $F$. cf. mexicanum cells were set up at each nutrient condition. The bottles were filled to capacity with freshly filtered oceanic seawater and capped. For each nutrient condition, $10 \mathrm{ml}$ aliquots were removed from 2 of the 6 experimental bottles and from 1 of each set of the 4 control bottles, filtered using GF/F filters, and stored frozen until $\mathrm{N}$ and $\mathrm{P}$ concentrations were determined. The remaining volume was fixed with Lugol's solution to determine the initial predator and prey concentrations.

The other experimental and control bottles were incubated for $2 \mathrm{~d}$ using a vertically rotating plate and an illumination of $100 \mu \mathrm{E} \mathrm{m} \mathrm{m}^{-2} \mathrm{~s}^{-1}$. After incubation a
$10 \mathrm{ml}$ aliquot from each bottle was GF/F filtered and stored frozen for determination of $\mathrm{N}$ and $\mathrm{P}$ concentrations. The remaining volume from each bottle was fixed and the final concentrations of predator and/or prey were determined as previously described.

Statistical analysis. A 1 -way ANOVA (Zar 1984) was used to test the effect of light intensity or nutrient concentration on ingestion rates of Fragilidium cf. mexicanum on Lingulodinium polyedrum.

\section{RESULTS}

\section{Prey species and feeding frequencies}

Fragilidium cf. mexicanum feeds on red-tide dinoflagellate prey by engulfment and can contain several prey cells simultaneously (Fig. 1). From the red-tide and toxic dinoflagellates offered as prey, $F$. cf. mexicanum ingested Lingulodinium polyedrum (Fig. 1A, B), Gymnodinium sanguineum (Fig. 1C), Scrippsiella trochoidea (Fig. 1D), Prorocentrum micans (Fig. 1E), and Prorocentrum minimum (Fig. 1F), but did not eat Amphidinium carterae or Cochlodinium polykrikoides. $F$. cf. mexicanum was observed to quickly attach to and easily engulf $L$. polyedrum and $S$. trochoidea cells as soon as they were offered, and usually engulfed a second prey cell soon thereafter. $F$. cf. mexicanum was able to ingest $3 \mathrm{~L}$. polyedrum cells within $10 \mathrm{~min}$. Feeding frequency $(\mathrm{FF})$ values of $F$. cf. mexicanum on $L$. polyedrum and $S$. trochoidea $>0$ and an average number of ingested prey cells inside the grazer (APN) $>1$ after the $2 \mathrm{~h}$ incubation quantitatively confirm these observations. However, F. cf. mexicanum did not quickly attach to and sometimes had difficulty engulfing $\mathrm{G}$. sanguineum and $P$. micans, even after capturing them. F. cf. mexicanum tried to ingest the longer lateral side of $G$. sanguineum and $P$. micans rather than the shorter apical side, and prey were able to escape after being captured. FF and APN values of 0 on these prey species after $2 \mathrm{~h}$ incubation confirm this observation. $F$ cf. mexicanum usually digested the prey cells offered after they had been completely engulfed

FFs of Fragilidium cf. mexicanum on red-tide dinoflagellates were significantly affected by prey species (maximum FFs on 5 edible prey species; ANOVA, p < 0.001 after both 2 and 72 h) (Figs. 2 to 5 ).

For the Lingulodinium polyedrum diet, FF was significantly affected by prey concentration (ANOVA, p < 0.01 after $2 \mathrm{~h}$ and $\mathrm{p}<0.001$ after $72 \mathrm{~h}$ ) (Fig 2A). FFs increased with increasing prey concentration below ca 300 and 800 cells $\mathrm{ml}^{-1}$ for the $2 \mathrm{~h}$ and $72 \mathrm{~h}$ incubations, respectively, but were saturated at higher concentrations. Maximum FFs were 20 and $44 \%$ for the $2 \mathrm{~h}$ and $72 \mathrm{~h}$ incubations, respectively. Maximum 

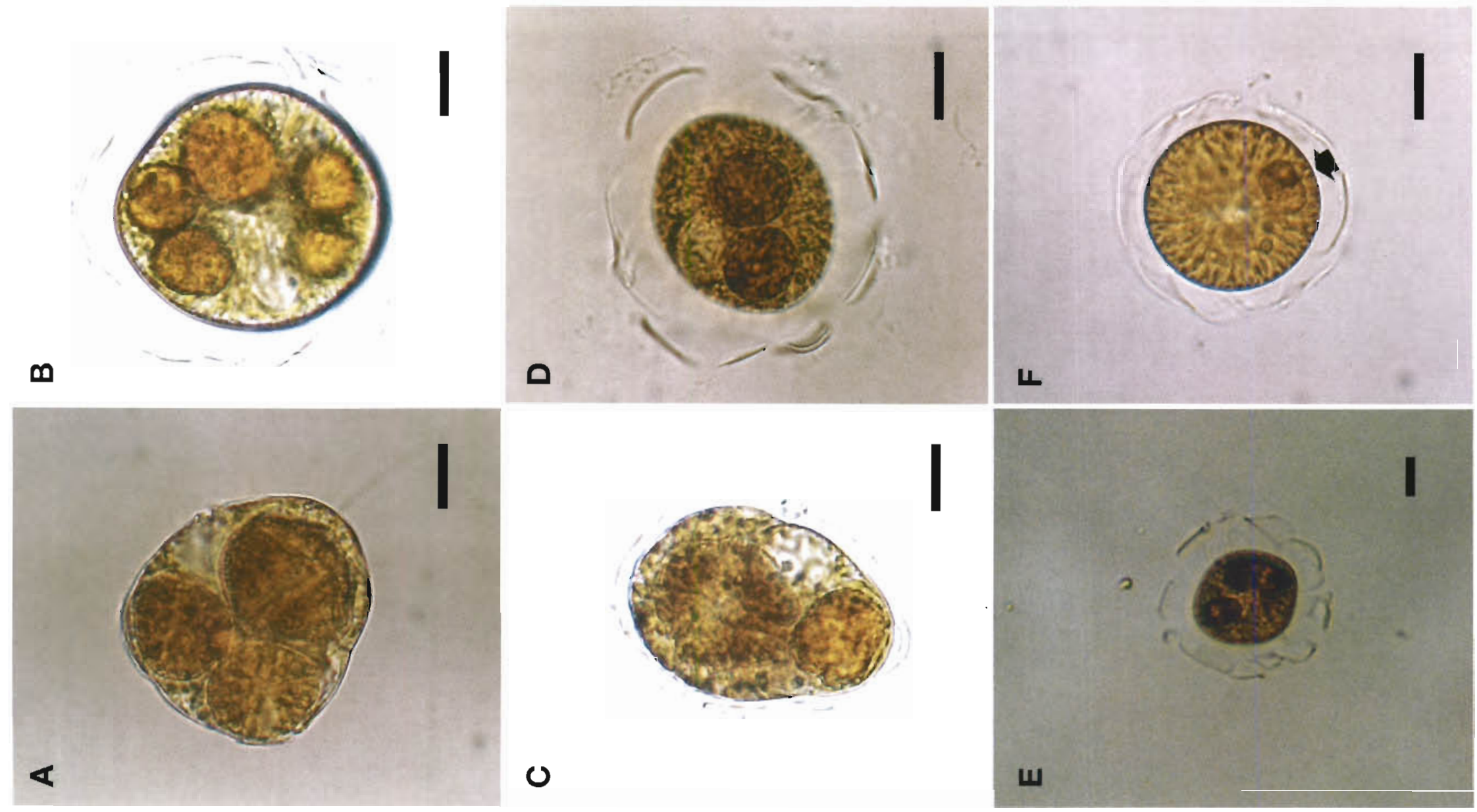

0

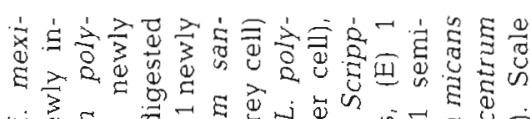

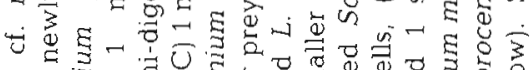

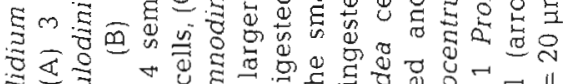

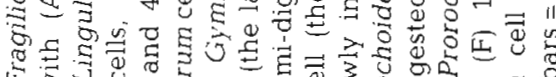

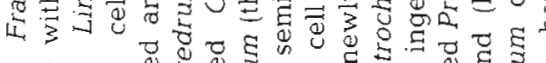

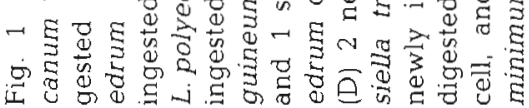



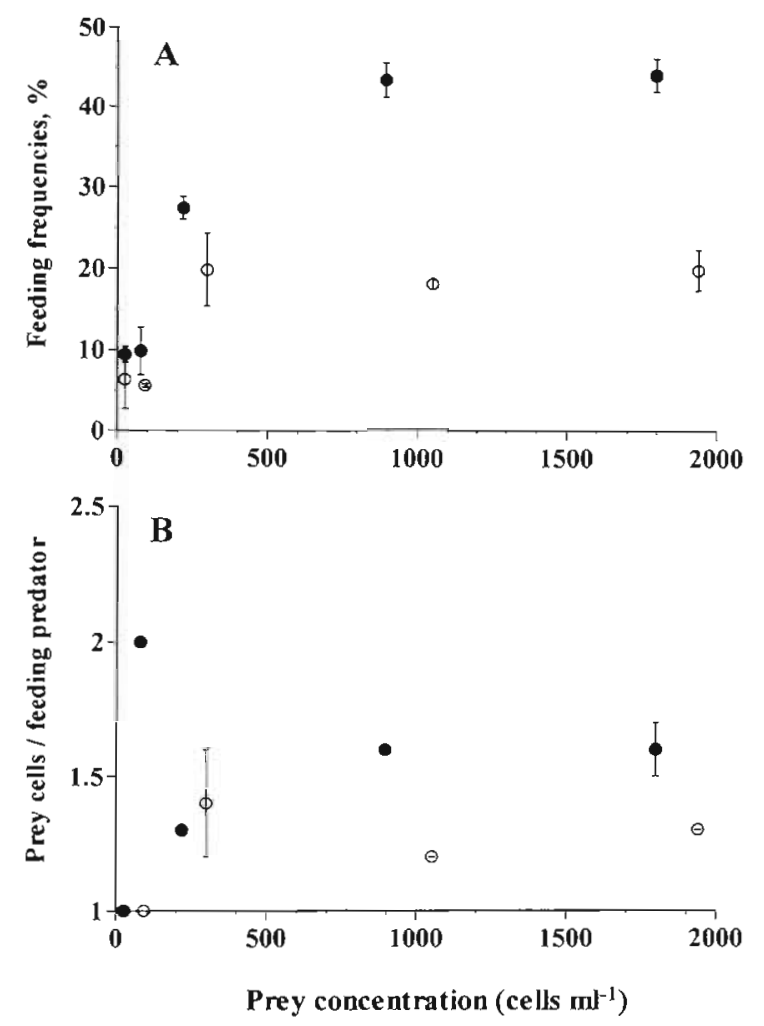

Fig. 2. Fragilidium cf. mexicanum. (A) Feeding frequency (\%) on Lingulodinium polyedrum as a function of final prey concentration. Feeding frequency is based on the proportion of the $F$. cf. mexicanum cells observed to contain prey and is measured by calculating the percent ratio of $F$. cf. mexicanum containing 1 or more target prey cells to total $F$. cf, mexicanum after $2 \mathrm{~h}(0)$ and $72 \mathrm{~h}(\bullet)$ incubations. (B) Average number of ingested prey in $F$. cf. mexicanum feeding on L. polyedrum, measured by calculating the average numbers of prey cells observed in the protoplasm of grazers that had fed after $2 \mathrm{~h}(0)$ and $72 \mathrm{~h}(\bullet)$ incubations. Data points show treatment mean $\pm 1 \mathrm{SE}$

numbers of prey observed inside the protoplasm of Fragilidium of. mexicanum (MPNs) after the $2 \mathrm{~h}$ and $72 \mathrm{~h}$ incubations were 3 and 6 , respectively. The average number of prey cells observed in the grazer's protoplasm (APN) was between 1 and 2 prey cells predator $^{-1}$ for $F$. cf. mexicanum feeding on $L$. polyedrum (Fig. 2B). APN was significantly affected by prey concentration (ANOVA, $p<0.05$ after $2 \mathrm{~h}$ and $\mathrm{p}<0.001$ after $72 \mathrm{~h}$ ) and generally increased with increasing prey concentration, with 1 exception $(2$ at $78 \mathrm{~L}$. polyedrum $\mathrm{ml}^{-1}$ ). After the $72 \mathrm{~h}$ incubation, densities of $F$. cf. mexicanum in experimental bottles were markedly higher than those in the control bottles.

For the Scrippsiella trochoidea diet, FF was significantly affected by prey concentration (ANOVA, p < 0.001 after both 2 and $72 \mathrm{~h}$ ). It increased with increasing prey concentration < ca 9100 cells $\mathrm{ml}^{-1}$ for both 2 and $72 \mathrm{~h}$ incubations, with saturation at higher con-
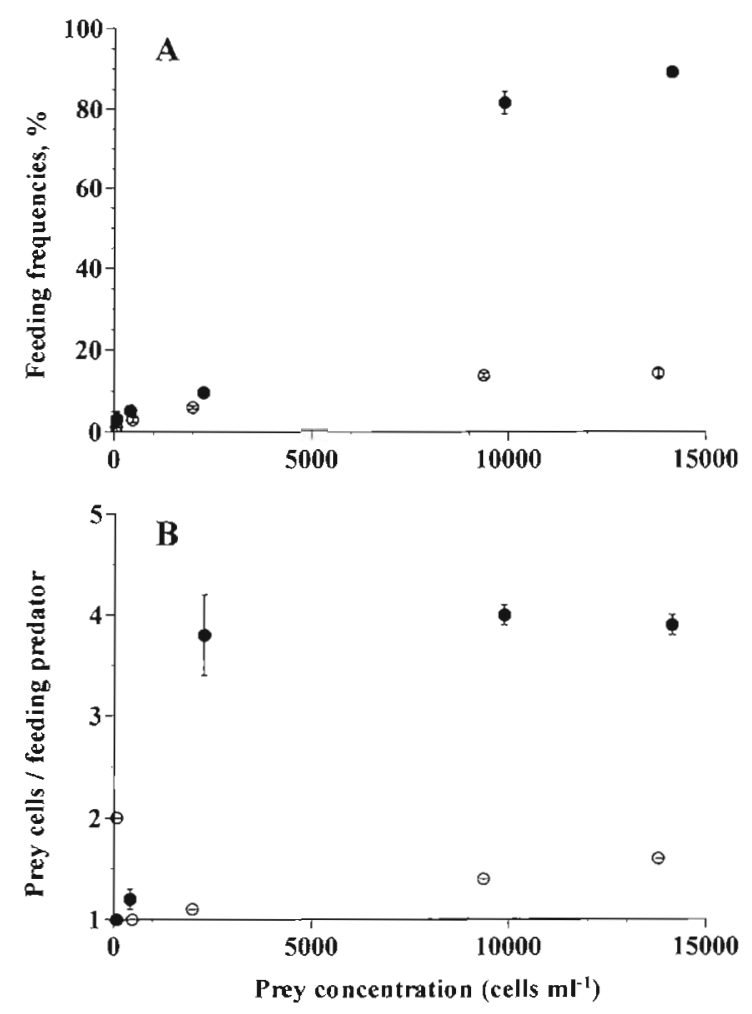

Fig. 3. Fragilidium cf. mexicanum. (A) Feeding frequency (\%) on Scrippsiella trochoidea and $(\mathrm{B})$ average number of ingested $S$. trochoidea after $2 \mathrm{~h}(0)$ and $72 \mathrm{~h}(\bullet)$ incubations. Data points show treatment mean $\pm 1 \mathrm{SE}$

centrations (Fig. 3A). MPNs after $2 \mathrm{~h}$ and $72 \mathrm{~h}$ incubations were 4 and 8 , respectively. APN was $\leq 2$ prey cells predator $^{-1}$ at all prey concentrations after the $2 \mathrm{~h}$ incubation and at prey concentrations $<400$ cells $\mathrm{ml}^{-1}$ after the $72 \mathrm{~h}$ incubation, but was between 3 and 4 at the higher prey concentrations in the $72 \mathrm{~h}$ incubation (Fig. 3B). APN was significantly affected by prey concentration after $72 \mathrm{~h}$ (ANOVA, $\mathrm{p}<0.001$ ), but was not significant affected after $2 \mathrm{~h}(\mathrm{p}>0.1)$. After the $72 \mathrm{~h}$ incubation, there was no clear difference between the densities of Fragilidium cf. mexicanum in the control and experimental bottles

For the Gymnodinium sanguineum diet, FFs were less than $2 \%$ (Fig. 4A), and were not significantly affected by prey concentration (ANOVA, p > 0.1), unlike the Lingulodinium polyedrum and Scrippsiella trochoidea diets. MPN after both the 2 and $72 \mathrm{~h}$ incubations was 3, while APN was 1 at all prey concentrations except 1920 cells $\mathrm{ml}^{-1}$ after the $72 \mathrm{~h}$ incubation, when it reached 2.2 prey cells grazer ${ }^{-1}$ (Fig. 4B).

For the Prorocentrum micans diet, FFs were zero after the $2 \mathrm{~h}$ incubation, but reached $5.6 \%$ in the $72 \mathrm{~h}$ incubation (Fig. 5A). FF was not significantly affected by prey concentration (ANOVA, $\mathrm{p}>0.1$ ), as with 

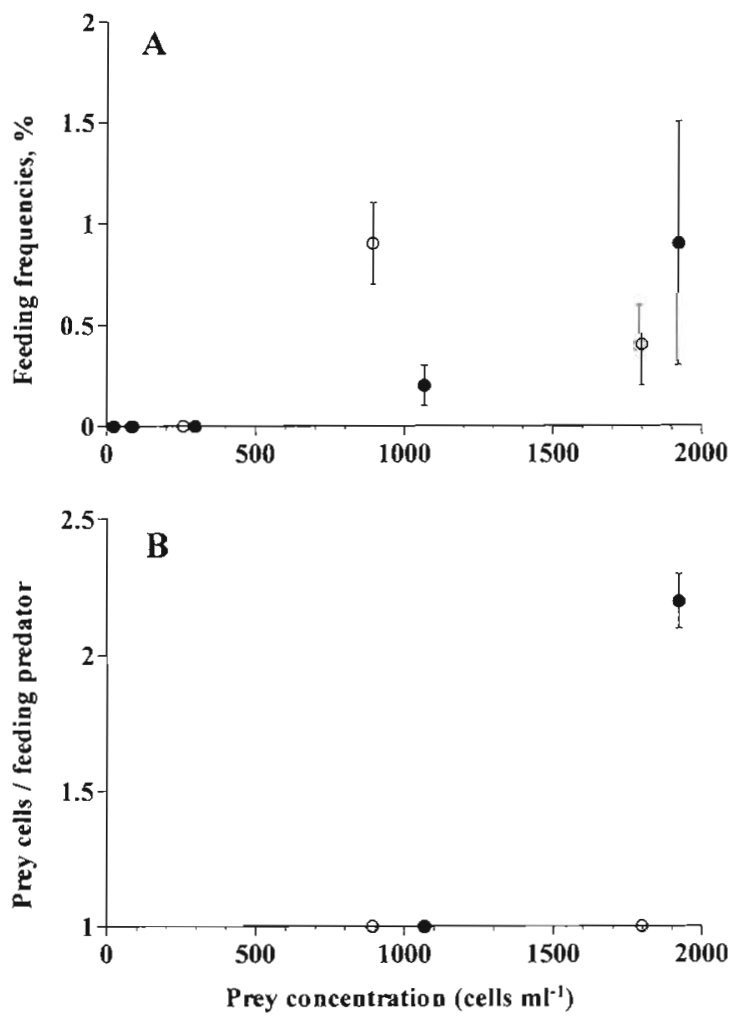

Fig. 4. Fragilidium cf. mexicanum. (A) Feeding frequency (\%) on Gymnodinium sanguineum and (B) average number of ingested $G$. sanguineum after $2 \mathrm{~h}(0)$ and $72 \mathrm{~h}(\bullet)$ incubations. Data points show treatment mean $\pm 1 \mathrm{SE}$

Gymnodinium sanguineum. MPN after the $72 \mathrm{~h}$ incubation was 2 and APN was almost 1 (Fig. 5B). APN was also not significantly affected by prey concentration after 72 h (ANOVA, p > 0.1).

For the Prorocentrum minimum diet, FFs were zero at the all prey concentrations except 70400 cells $\mathrm{ml}^{-1}$ in the $72 \mathrm{~h}$ incubation (9.6\%). MPN after the $72 \mathrm{~h}$ incubation was 6 and APN was 1.6 prey cells predator ${ }^{-1}$. Feeding by Fragilidium cf. mexicanum on P. minimum at high prey concentrations was ascertained through an additional experiment.

For the Amphidinium carterae and Cochlodinium polykrikoides diets, FFs were zero at the all prey concentrations offered in the present study.

\section{Swimming speed}

Average $( \pm \mathrm{SE}$ ) and maximum swimming speeds of Fragilidium cf. mexicanum, $353( \pm 17)$ and $448 \mu \mathrm{m} \mathrm{s}^{-1}$ respectively, were greater than those of all prey species except Cochlodinium polykrikoides, which had average and maximum speeds of 1063 ( \pm 84) and $1449 \mathrm{\mu m} \mathrm{s}^{-1}$ respectively (Table 3 ).
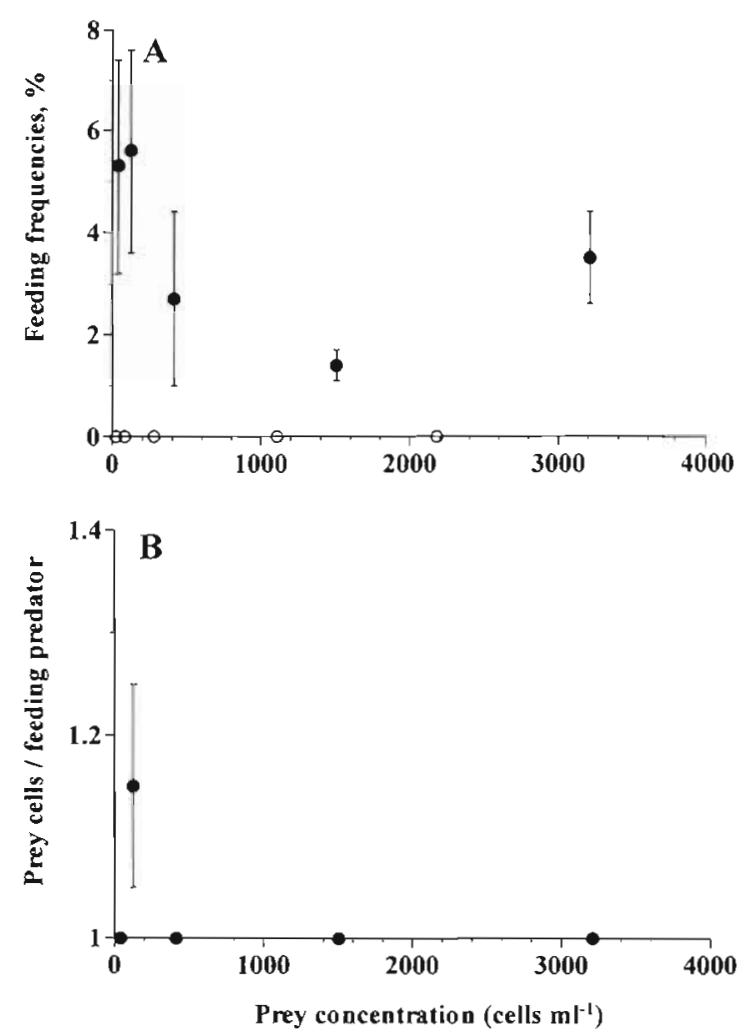

Fig. 5. Fragilidium cf. mexicanum. (A) Feeding frequency (\%) on Prorocentrum micans and (B) average number of ingested $P$. micans after $2 \mathrm{~h}(0)$ and $72 \mathrm{~h}(\bullet)$ incubations. Data points show treatment mean $\pm 1 \mathrm{SE}$

\section{Prey selectivity in prey mixtures}

The preference of Fragilidium cf. mexicanum for a particular diet was determined from the ratio of ingestion rates for Lingulodinium polyedrum and Scrippsiella trochoidea as a function of the ratio of the mean prey concentrations (Fig. 6). All data points were above the 1:1 line (line of no preference), indicating that $F$. cf. mexicanum strongly preferred L. polyedrum to $S$. trochoidea

Table 3. Swimming speeds ( $\mu \mathrm{m} \mathrm{s}^{-1}$ ) of species used in the present study at $22^{\circ} \mathrm{C}$

\begin{tabular}{|lcc|}
\hline Species & Mean $( \pm \mathrm{SE})$ & Maximum \\
\hline Prorocentrum minimum & $157( \pm 8)$ & 194 \\
Amphidinium carterae & $111( \pm 3)$ & 126 \\
Cochlodinium polykrikoides & $1063( \pm 84)$ & 1449 \\
Scrippsiella trochoidea & $304( \pm 12)$ & 348 \\
Prorocentrum micans & $268( \pm 21)$ & 380 \\
Gymnodinium sanguineum & $193(+10)$ & 280 \\
Lingulodinium polyedrum & $282( \pm 15)$ & 378 \\
Fragilidium cf. mexicanum & $353( \pm 17)$ & 448 \\
\hline
\end{tabular}




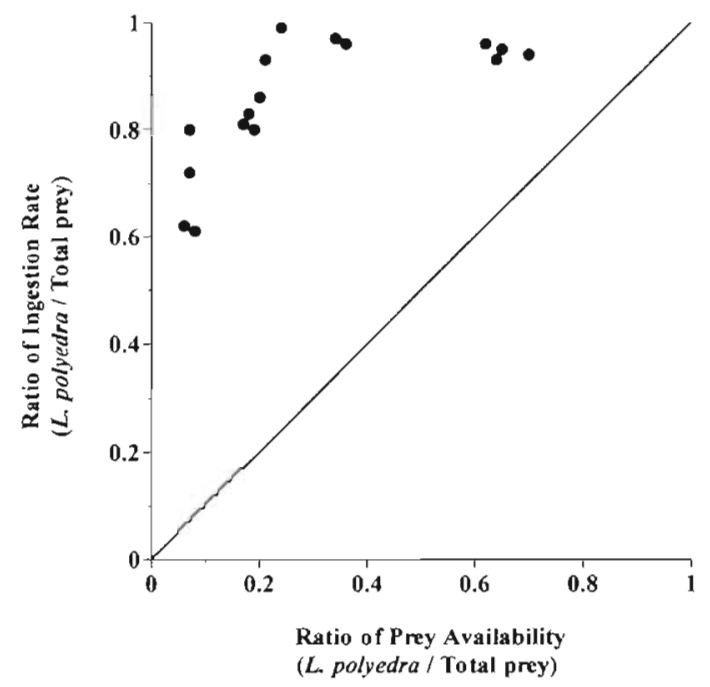

Fig. 6. Fragilidium of. mexicanum. Prey selection in a mixed diet of Lingulodinium polyedrum and Scrippsiella trochoidea. Data points show results of single incubation bottles. The carbon ratio of the ingestion rate of $F$. cf. mexicanum on $L$. polyedrum to that on total prey ( $L$. polyedrum $+S$. trochoidea) was expressed as a function of prey availability ( $L$. polyedrum carbon/total prey carbon)

\section{Growth and ingestion rates of Fragilidium cf. mexicanum}

Specific growth rates of Fragilidium cf. mexicanum fed on Lingulodinium polyedrum increased rapidly with increasing mean prey concentration for prey

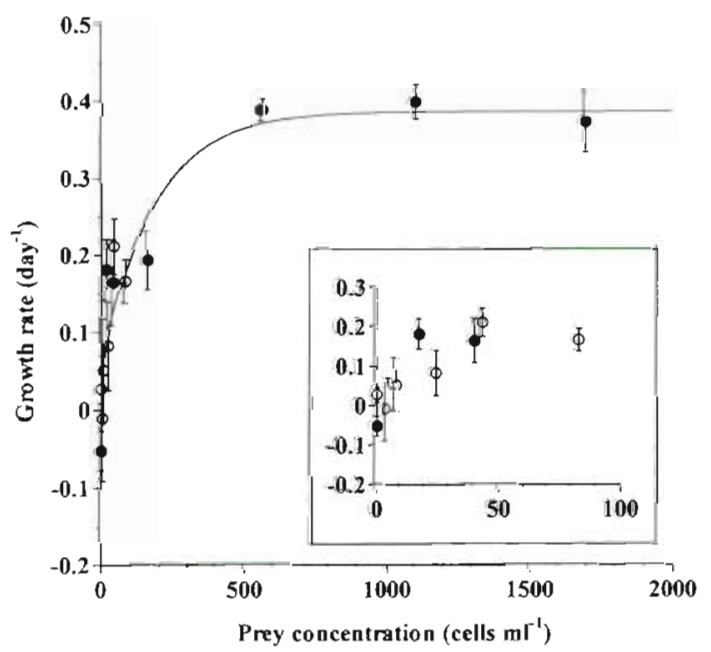

Fig. 7. Fragilidium cf. mexicanum. Specific growth rate on a diet of Lingulodinium polyedrum as a function of mean prey concentration $(c)$. Data points show treatment means $\pm 1 \mathrm{SE}$. The equation of the regression line was obtained by pooling all treatments from Expts $8(0)$ and $9(\bullet)$. The fitted curve is the Ivlev model. Growth rate $\left(\mathrm{GR}, \mathrm{d}^{-1}\right)=0.36\left(1-\mathrm{e}^{-0.0142 \mathrm{c}}\right)$, $\mathrm{R}^{2}=0.762$. Inset shows values at low prey concentrations concentrations $<500$ cells ml $^{-1}$, but were saturated at higher concentrations (Fig. 7). The maximum specific growth rate under a $12 \mathrm{~h}$ light: $12 \mathrm{~h}$ dark cycle of illumination at $20 \mathrm{\mu E} \mathrm{m}^{-2} \mathrm{~s}^{-1}$, obtained at a mean prey concentration of approximately 500 cells $\mathrm{ml}^{-1}$ in Expt 8, was $0.36 \mathrm{~d}^{-1}$. Growth rate of $F$. cf. mexicanum without added prey (in 12 control bottles) was $-0.05 \pm 0.03$ (mean $\pm \mathrm{SE}$ ).

The ingestion rate of Fragilidium cf. mexicanum feeding on Lingulodinium polyedrum increased with increasing mean prey concentration to a maximum of 3.9 prey grazer ${ }^{-1} \mathrm{~d}^{-1}$, with saturation at mean prey con-

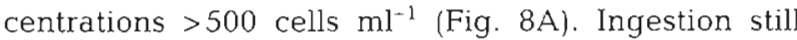
occurred at mean prey concentrations $<10$ cells $\mathrm{ml}^{-1}$. Clearance rates decreased with increasing mean prey concentration (Fig. 8B), with a maximum clearance rate of $6 \mu$ grazer $^{-1} \mathrm{~h}^{-1}$ at a mean prey concentration of approximately 20 cells $\mathrm{ml}^{-1}$.
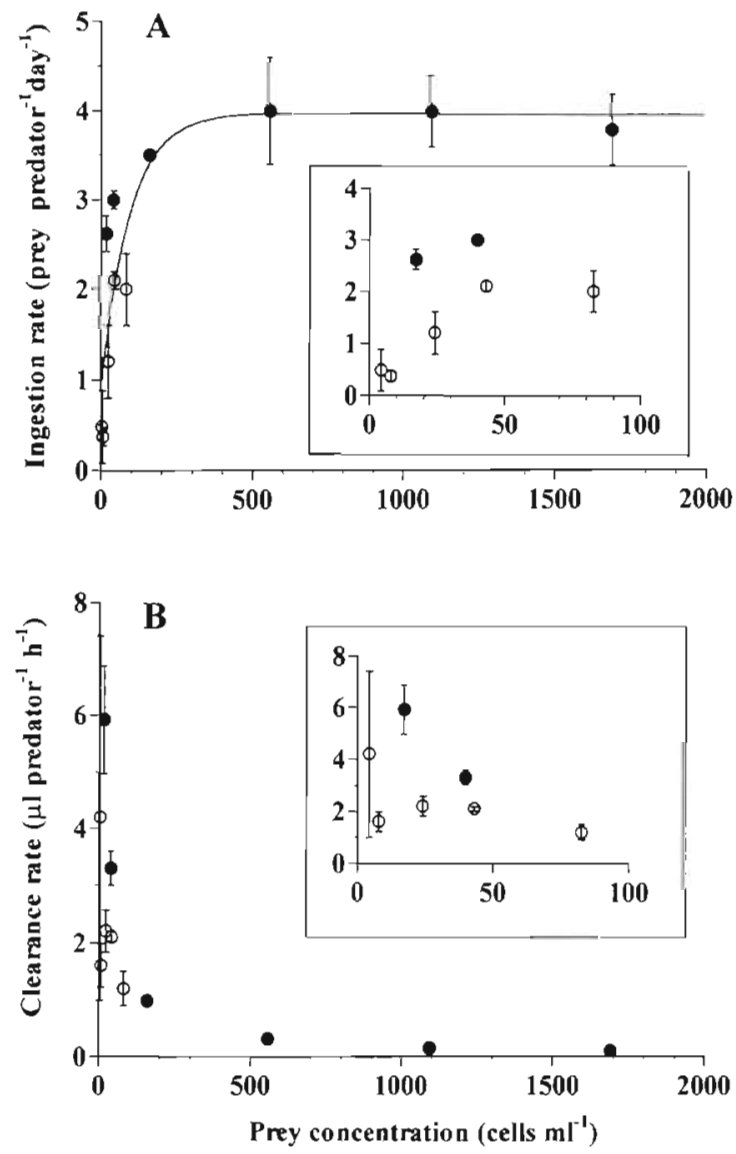

Fig. 8. Fragilidium cf mexicanum. (A) Ingestion rate and (B) clearance rate on Lingulodinium polyedrum as a function of mean prey concentration (C). Data points show treatment means $\pm 1 \mathrm{SE}$. The regression line in (A) was obtained by pooling all treatments from the Expts $8(0)$ and $9(\bullet)$. The fitted curve is the Ivlev model. Ingestion rate (IR, prey grazer ${ }^{-1}$ $\left.\mathrm{d}^{-1}\right)=3.9\left(1-\mathrm{e}^{-0.0202 c}\right), \mathrm{R}^{2}=0.809$. Insets show values at low prey concentrations 
Growth yields were between 15 and $53 \%$, and the value at the mean prey concentration for which the maximum growth rate was achieved was $39 \%$.

\section{Light and nutrient effects on ingestion rate}

Ingestion rates of Fragilidium cf. mexicanum feeding on Lingulodinium polyedrum under food-satiated conditions at light intensities ranging from 20 to $200 \mu \mathrm{E}$ $\mathrm{m}^{-2} \mathrm{~s}^{-1}$ were 3.0 to 3.8 prey grazer ${ }^{-1} \mathrm{~d}^{-1}$; however, they were not significantly different from one another (ANOVA, $\mathrm{p}>0.1$ ) (Fig. 9).

Ingestion rates of Fragilidium cf. mexicanum feeding on Lingulodinium polyedrum when food-satiated under different nutrient conditions (OC, F-N-P, F$N, F-P$, and F) were between 3.4 and 4.2 prey grazer $^{-1}$ $\mathrm{d}^{-1}$, but showed no significant difference among treatments (ANOVA, p > 0.1) (Fig. 10).

\section{DISCUSSION}

The present study shows that (1) Fragilidium cf. mexicanum can feed on diverse red-tide dinoflagellate species, (2) F. cf. mexicanum has a wide range of feeding frequencies (FFs) which were affected by prey species, (3) FFs on Lingulodinium polyedrum and Scrippsiella trochoidea were affected by prey concentration, but FFs on the other prey species offered under the same experimental conditions were not, (4) F. cf. mexicanum strongly selects $L$, polyedrum over $S$. trochoidea in prey mixtures, (5) the unialgal diet of L. polyedrum clearly supported the grazer's phago-

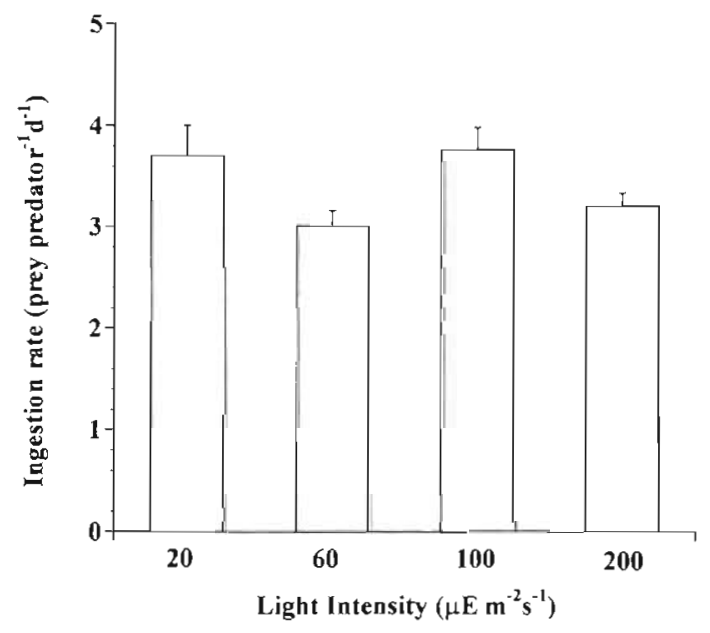

Fig. 9. Fragilidium cf. mexicanum. Ingestion rate on Lingulodinium polyedrum as a function of light intensity. Values are treatment means $+1 \mathrm{SE}$

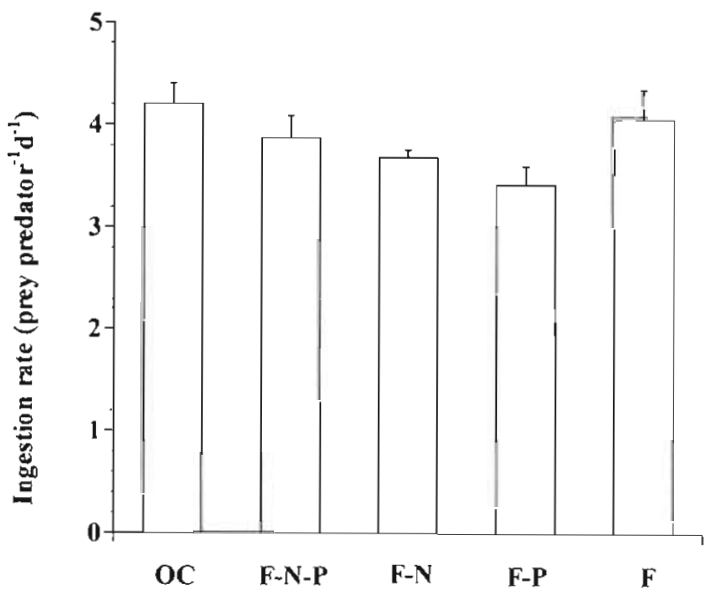

Fig. 10. Fragilidium cf. mexicanum. Ingestion rate on Lingulodinium polyedrum under different nutrient conditions. Values are treatment means $+1 \mathrm{SE}$. Media used were oceanic seawater (OC), $f / 2$ medium without $N$ and $P(F-N-P), f / 2$ medium without $N(F-N), f / 2$ medium without $P(F-P)$, and $f / 2$ medium (F) (see 'Materials and methods: nutrient effects on feeding'). During this experiment, initial and final concentrations of $\mathrm{N}$ (and P) were 0.18 and $0.12 \mu \mathrm{M} \mathrm{N}(0.17$ and $0.04 \mu \mathrm{MP})$ in the $\mathrm{OC}$ bottles, 0.01 and $0.02 \mu \mathrm{MN}(0.22$ and $0.02 \mu \mathrm{MP})$ in the $\mathrm{F}-\mathrm{N}$ $\mathrm{P}$ bottles, nd (not detectable) $\mu \mathrm{MN}$ (37 and $18 \mu \mathrm{MP}$ ) in the $\mathrm{F}-\mathrm{N}$ bottles, 205 and $159 \mu \mathrm{MN}$ (nd $\mu \mathrm{M} \mathrm{P}$ ) in the $\mathrm{F}-\mathrm{P}$ bottles, and 225 and $153 \mu \mathrm{MN}$ (40 and $19 \mu \mathrm{MP}$ ) in the F bottles

trophic growth under conditions unfavorable to its phototrophic growth, and (6) the ingestion rate of $F$. cf. mexicanum on L. polyedrum was not significantly affected by light intensity or nutrient concentration.

\section{Prey species and selection}

Unlike Fragilidium subglobosum, which is known to feed exclusively on Ceratium spp. (Skovgaard 1996a), $F$. cf. mexicanum can feed on red-tide dinoflagellates belonging to diverse genera. Lingulodinium polyedrum, Gymnodinium sanguineum, Prorocentrum micans, $P$. minimum, and Scrippsiella trochoidea, species that most frequently form red tides in the coastal waters off southern Californian where the grazer was isolated, are all ingested.

The FF of Fragilidium cf. mexicanum feeding on different prey species and its selectivity in prey mixtures might be affected by several factors, including prey size, shape, taste, and swimming speed. When provided unialgal diets, $F$. cf. mexicanum had much higher feeding frequencies on Lingulodinium polyedrum and Scrippsiella trochoidea than on Gymnodinium sanguineum, Prorocentrum micans, and $P$. minimum. L. polyedrum and $S$. trochoidea may be nutritionally better prey for $F$. cf. mexicanum, or $F$. cf. mexicanum may have more difficulty capturing and/or 
engulfing $G$. sanguineum, Prorocentrum micans, and $P$. minimum. The large ciliates Favella sp. (Jeong 1995) and Strombidinopsis sp. (ca $200 \mu \mathrm{m}$ in cell length) (Jeong et al. 1999), the calanoid copepod Calanus pacificus (Huntley et al. 1983, 1987), and the larval northern anchovy Engraulis mordax (Scura \& Jerde 1977) have higher maximum growth and/or development rates when feeding on $G$. sanguineum than on $L$. polyedrum or $S$. trochoidea. The C:N ratio of $G$. sanguineum (5.4) is lower than that of $L$. polyedrum (8.9) and $S$. trochoidea (9.1) (Fernández 1979). Therefore, it is unlikely that $L$. polyedrum and $S$. trochoidea are nutritionally better prey than $G$. sanguineum, $P$. micans, and P. minimum.

Lingulodinium polyedrum and Scrippsiella trochoidea have an almost spherical shape, while Gymnodinium sanguineum, Prorocentrum micans, and $P$. minimum are flat and long. While Fragilidium cf. mexicanum easily engulfed $L$. polyedrum and $S$. trochoidea, we found that it had difficulty ingesting $G$. sanguineum and $P$. micans because it tried to ingest the longer lateral side rather than the shorter apical side of these prey. Thus, $F$. cf. mexicanum failed to engulf $G$. sanguineum and $P$. micans even after capturing them. While F. subglobosum can ingest long Ceratium tripos cells from the apical or antapical side by gradually digesting part of the prey during engulfing (Skovgaard 1996a), F cf. mexicanum appears unable to do this with $G$. sanguineum and $P$. micans cells. These prey might be strong enough to escape this type of gradual digestion or their large cell length and/or flat shape may prevent them from being engulfed by $F$. cf. mexicanum.

The maximum growth rates and/or feeding frequencies of the heterotrophic dinoflagellates Protoperidinium cf divergens and $P$. crassipes on Lingulodinium polyedrum and Scrippsiella trochoidea are also higher than for Gymnodinium sanguineum and Prorocentrum spp. (Jeong \& Latz 1994). Another heterotrophic dinoflagellate, Noctiluca scintillans, has much higher growth rates when feeding on L. polyedrum than on G. sanguineum (Jeong 1995). Protoperidinium spp., which feed using a pallium, and Noctiluca spp., which feed using a tentacle, also have more difficulty capturing and/or ingesting G. sanguineum cells than they do L. polyedrum and $S$. trochoidea cells. Since Fragilidium cf. mexicanum has a diet similar to that of co-occurring $P$. cf. divergens, $P$. crassipes, and $N$. scintillans, it may compete with these other grazers for $L$. polyedrum and $S$. trochoidea as prey.

Fragilidinium cf. mexicanum did not feed on Amphidinium carterae and Cochlodinium polykrikoides. A. carterae is known to be toxic (Steidinger \& Tangen 1996), and it is also poor prey for the tintinnid ciliate Favella ehrenbergii (Stoecker et al. 1981) and the naked ciliate Strombidinopsis sp. (Jeong et al. 1999). Thus, the bad taste of $A$. carterae might be responsible for the zero FF found in this study. F cf. mexicanum might have difficulty in catching $C$. polykrikoides cells because it has a much slower swimming speed than this prey species. It is interesting that several studies have reported that Fragilidium spp. feed intensively on Lingulodinium polyedrum or Alexandrium spp. in natural water samples (Balech \& Ferrando 1964 Eppley \& Harrison 1975, Balech 1988), while there are no comparable reports that Fragilidium spp. feeds on the other prey species investigated in the present study.

\section{Prey selectivity in prey mixture}

The present study shows that Fragilidium cf. mexicanum has the ability to feed selectively when offered a prey mixture of red-tide dinoflagellates. $F$. cf. mexicanum strongly preferred Lingulodinium polyedrum to Scrippsiella trochoidea, although the maximum FF on $S$. trochoidea was similar to or higher than that on $L$. polyedrum when a unialgal diet was provided (Figs. 2 $\& 3)$. Prey selection by dinoflagellates in mixtures of prey species is common. Hansen \& Nielsen (1997) concluded that $F$. subglobosum has a prey preference, showing a higher uptake rate on Ceratium tripos than on C. furca or C. fusus when unialgal diets were provided. Protoperidinium cf. divergens strongly selected L. polyedrum over Gymnodinium sanguineum (Jeong \& Latz 1994) and round copepod eggs with a smooth surface over L. polyedrum (Jeong 1996). Oxyrrhis marina also has the ability to select prey among differently sized nanophytoplankton (Hansen et al. 1996). This differential feeding in a prey mixture may affect the population dynamics of the red-tide dinoflagellates when favorable conditions for their growth are provided in nature.

\section{Growth and ingestion}

A unialgal diet of Lingulodinium polyedrum can support population growth of Fragilidium cf. mexicanum under conditions under which its growth rate, without added prey, is negative or zero. This evidence suggests that $F$. cf. mexicanum can increase its population by feeding on $L$. polyedrum under conditions unfavorable for phototrophic growth. For the Scrippsiella trochoidea diet, the maximum FF was higher than that for L. polyedrum prey; however, there was no clear difference between the densities of Fragilidium cf. mexicanum in control and experimental bottles after $72 \mathrm{~h}$ incubation. This evidence suggests that the 

phagotrophic growth of $F$. cf. mexicanum even though the grazer can actively feed on it, an observation that has also been made for the heterotrophic dinoflagellate Protoperidinium cf. divergens (Jeong \& Latz 1994).

The pattern in the specific growth rate of Fragilidium cf. mexicanum feeding on Lingulodinium polyedrum was similar to those of Protoperidinium cf. divergens and $P$. crassipes feeding on the same prey (Jeong \& Latz 1994). Maximum mixotrophic growth rate of $F$.cf. mexicanum on $L$. polyedrum under a $12 \mathrm{~h}$ light: $12 \mathrm{~h}$ dark cycle of illumination at $20 \mu \mathrm{E} \mathrm{m}^{-2} \mathrm{~s}^{-1}$ was $0.36 \mathrm{~d}^{-1}$, comparable to that achieved by $P$. crassipes, but lower than that achieved by $P$. cf. divergens (Table 4). Mean $L$. polyedrum concentration at which the maximum growth and ingestion rates of $F$. cf. mexicanum were achieved, 500 cells $\mathrm{ml}^{-1}$, is also similar to that for $P$. crassipes, but is lower than that for $P$. cf. divergens, which achieves maximum growth and ingestion rates at 1100 to 1500 cells $\mathrm{ml}^{-1}$. Therefore, phagotrophic growth of $F$. cf. mexicanum on $L$. polyedrum is comparable to that of $P$. crassipes on the same prey.

The maximum clearance rate of Fragilidium cf. mexicanum feeding on Lingulodinium polyedrum, $6 \mu \mathrm{l}$ predator ${ }^{-1} \mathrm{~h}^{-1}$, is much higher than that of Protoperidinium cf. divergens or $P$. crassipes $(0.9$ and $0.6 \mu \mathrm{l}$ predator $^{-1} \mathrm{~h}^{-1}$ ). At low $L$. polyedrum concentrations, the engulfment process of $F$. cf. mexicanum may be more efficient in capturing and ingesting prey than the pallium feeding of Protoperidinium spp. An efficient feeding mechanism might enable $F$. cf. mexicanum to dominate Protoperidinium spp. under reciprocal predation in darkness (Jeong et al. 1997), even though the maximum ingestion rates of $F$. cf. mexicanum feeding on $L$. polyedrum, 3.9 prey predator ${ }^{-1} \mathrm{~d}^{-1}$, were lower unialgal diet of $S$. trochoidea does not support the

than that of $P$. cf. divergens $\left(6.1\right.$ prey predator $\left.{ }^{-1} \mathrm{~d}^{-1}\right)$ (Table 4).

The maximum clearance rate $\left(6 \mu l\right.$ predator $\left.^{-1} \mathrm{~h}^{-1}\right)$ of Fragilidium cf. mexicanum feeding on Lingulodinium polyedrum was slightly lower than that of F. subglobosum on Ceratium tripos, 7 ul predator ${ }^{-1} \mathrm{~h}^{-1}$ (Hansen \& Nielsen 1997), when corrected to $22^{\circ} \mathrm{C}$ using a $Q_{10}$ of 2.8 (Hansen et al. 1997).

Grazing of Fragilidium subglobosum on Ceratium tripos as a function of prey concentration is a Holling Type I curve (Hansen \& Nielsen 1997) because F. subglobosum encysts after ingesting only $1 \mathrm{C}$. tripos cell. Grazing of $F$. cf. mexicanum on Lingulodinium polyedrum is close to a Holling Type 2 curve (Holling 1959). The ingestion rate of $F$. cf. mexicanum on $L$. polyedrum is likely to be affected mainly by encounter rate between predator and prey at prey concentrations $<500$ cells $\mathrm{ml}^{-1}$ and mainly by handling time at higher prey concentrations. F. cf. mexicanum can contain several $L$. polyedrum cells inside its protoplasm simultaneously.

\section{Light and nutrient effects}

When prey was plentiful, ingestion rates of Fragilidjum cf. mexicanum feeding on Lingulodinium polyedrum under the light conditions provided in the present study $\left(20,60,100\right.$, and $\left.200 \mu \mathrm{E} \mathrm{m}^{-2} \mathrm{~s}^{-1}\right)$ were not significantly affected by light intensity (see Fig. 9). This is unlike the response of $F$. subglobusum feeding on Ceratium lineatum and C. tripos, for which ingestion rates were affected by light intensity from 0 to $150 \mu \mathrm{E} \mathrm{m} \mathrm{m}^{-2} \mathrm{~s}^{-1}$ and 10 to $45 \mu \mathrm{E} \mathrm{m} \mathrm{m}^{-2} \mathrm{~s}^{-1}$, respectively (Skovgaard 1996b, Hansen \& Nielsen 1997).

The mixotrophic dinoflagellate Prorocentrum minimum has been shown

Table 4. Comparison of growth and feeding by Fragilidium cf. mexicanum, Protoperidinium cf. divergens and P. crassipes on their optimal dinoflagellate prey, Lingulodinium polyedrum. $\mu_{\operatorname{rnax}}$ : maximum growth rate. $I_{\max }$ : maximum ingestion rate. PCMG: prey concentration at which maximum growth rate was achieved. PCMI: prey concentration at which maximum ingestion rate was achieved. $C_{\max }$ maximum clearance rate. $\mu_{\max }$ of $F$. cf. mexicanum is its maximum mixotrophic growth rate under a $12 \mathrm{~h}$ light: $12 \mathrm{~h}$ dark cycle of illumination at $20 \mu \mathrm{E} \mathrm{m}^{-2} \mathrm{~s}^{-1}$, but it could be phagotrophic growth because there was no phototrophic growth without added prey (see text). Data on feeding by Protoperidinium spp. were obtained from Jeong \& Latz (1994); $\mu_{\max }, I_{\max }$, and $C_{\max }$ are corrected to $22^{\circ} \mathrm{C}$ using $Q_{10}=2.8$ (Hansen et al 1997)

\begin{tabular}{|c|c|c|c|}
\hline & cf. mexicanum & P. cf. divergens & P. crassipes \\
\hline Nutritional mode & Mixotrophic & Heterotrophic & Heterotrophic \\
\hline Feeding mechanism & Engulfment & Pallium feeding & Pallium feeding \\
\hline Volume $\left(\mu \mathrm{m}^{3}\right)$ & 84600 & 119000 & 204000 \\
\hline$\mu_{\max }\left(\mathrm{d}^{-1}\right)$ & 0.36 & 0.66 & 0.42 \\
\hline$I_{\max }\left(\right.$ prey predator $\left.^{-1} \mathrm{~d}^{-1}\right)$ & 3.9 & 6.1 & 2.9 \\
\hline PCMG and PCMI (cells $\mathrm{ml}^{-}$ & $\left.\mathrm{al}^{-1}\right) \quad 500$ & 1100 & 700 \\
\hline$C_{\max }\left(\mu \mathrm{l}\right.$ predator $\left.{ }^{-1} \mathrm{~h}^{-1}\right)$ & 6 & 0.9 & 0.6 \\
\hline
\end{tabular}
to have higher feeding frequency at lower nutrient concentrations and to stop feeding when high concentrations of nitrate and phosphate were added together (Stoecker et al. 1997). However, the ingestion rate of Fragilidium cf. mexicanum feeding on Lingulodinium polyedrum was not significantly affected by nutrient concentration when the prey was plentiful, and the grazer did not stop feeding after being incubated with the addition of high concentrations of nitrate plus phosphate (see Fig. 10). Therefore, phagotrophic feeding by $F$. cf. mexicanum on $L$. polyedrum may be primarily a strategy for obtaining carbon rather than inorganic nutrients. 
Under the light and nutrient conditions provided in the present study, $F$. cf. mexicanum fed on $L$. polyedrum much like a heterotrophic dinoflagellate, regardless of the light intensity and nutrient concentration.

\section{Grazing impact}

While there have been several reports of intensive feeding by Fragilidium spp. on red-tide dinoflagellates in natural samples (Balech \& Ferrando 1964, Eppley \& Harrison 1975), it is presently impossible to estimate grazing impact of Fragilidium spp. on red-tide populations due to the lack of quantitative data on the abundance of Fragilidium spp. Therefore, we can only infer the relative grazing impact. The ingestion rate of $F$. cf. mexicanum feeding on Lingulodinium polyedrum was between those of Protoperidinium cf. divergens and $P$. crassipes. Therefore, if $F$ cf. mexicanum is as abundant as Protoperidinium spp., it may have a grazing impact on the populations of $L$. polyedrum similar to that of Protoperidnium spp. Fragilidium spp. might have a much lower grazing impact on populations of Gymnodinium sanguineum, Prorocentrum micans, or P. minimum than on L. polyedrum and Scrippsiella trochoidea, and may have no impact on the populations of Amphidinium carterae or Cochlodinium polykrikoides. To better understand the grazing impact by Fragilidium spp. on red-tide dinoflagellates, we will need to measure the abundance of Fragilidium spp. and red-tide dinoflagellates in the field.

Acknowledgements. We thank Michael Mullin and Peter Franks for comments on the manuscript. We also thank Michael Latz for collecting and sending water samples and Seong Min Koh and Soo Kyeong Kim for technical support. This paper is funded by a grant from Korean Science Foundation (grant no. 971-0403-012-2).

\section{LITERATURE CITED}

Balech E (1988) Una especie nueva del genero Fragilidium (Dinoflagellata) de la Bahfa de Chamela, Jalisco, Mexico. An Inst Biol Univ Nac Auton Mex Ser Zool 58:479-486

Balech E (1990) Four new dinoflagellates. Helgol Meeresunters $44: 387-396$

Balech E, Ferrando HJ (1964) Fitoplancton marino. Editorial, Univ Buenos Aires

Bockstahler KR, Coats DW (1993) Grazing of the mixotrophic dinoflagellate Gymnodinium sanguineum on ciliate populations of Chesapeake Bay. Mar Biol 116:447-487

Cheng JY, Antia NJ (1970) Enhancement by glycerol of photoheterotrophic growth of marine planktonic algae and its significance to the ecology of glycerol pollution. J Fish Res Bd Can 27:335-346

Eppley RW, Harrison WG (1975) Physiological ecology of Gonyaulax polyedrum, a red tide water dinoflagellate of southern California. In: Locicero VR (ed) Proc 1st Int Conf Toxic Dinoflagellate Blooms. Massachusett.s Science and
Technology Foundation, Wakefield, p 11-22

Furnández F (1979) Nutrition studies in the nauplius larva of Calanus pacificus (Copepoda: Calanoida). Mar Biol 53: $131-147$

Frost BW (1972) Effects of size and concentration of food particles on the feeding behavior of the marine planktonic cupepod Calanus pacificus. Limnol Oceanogr 17:805-815

Granéli $E$, Anderson DM, Carlsson P, Maestrini SY (1997) Light and dark carbon uptake by Dinophysis species in comparison to other photosynthetic and heterotrophic dinoflagellates. Aquat Microb Ecol 13:177-186

Givilard RRL, Ryther JH (1962) Studies of marine planktonic diatoms. 1. Cyclotella nana Hustedt and Detonula confervacea (Cleve) Grun. Can J Microbiol 8:229-239

Hansen FC, Witte HJ, Passarge J (1996) Grazing in the heterotrophic dinoflagellate Oxyrrhis marina: size selectivity and preference for calcified Emiliania huxleyi cells. Aquat Microb Ecol 10:307-313

Hansen PJ, Nielsen TG (1997) Mixotrophic feeding of Fragilidium subglobosum (Dinophyceae) on three species of Ceratium: effects of prey concentration, prey species and light intensity. Mar Ecol Prog Ser 147:187-196

Hansen PJ, Bjornsen PK, Hansen BW (1997) Zooplankton grazing and growth: scaling within the $2-2000-\mathrm{mm}$ body size range. Limnol Oceanogr 42:687-704

Heinbokel JF (1978) Studies on the functional role of tintinnids in the Southern California Bight. I. Grazing and growth rates in laboratory cultures. Mar Biol 47:177-189

Holling CS (1959) Some characteristics of simple types of predation and parasitism. Can Entomoi 91:385-398

Holmes RW, Williams PM, Eppley RW (1967) Red water in La Jolla Bay, 1964-1966. Limnol Oceanogr 12:503-512

Huntley ME, Barthel KG, Star JL (1983) Particle rejection by Calanus pacificus: discrimination between similarly sized particles. Mar Biol 74:151-160

Huntley ME, Climiniello P, Lopez MDG (1987) Importance of food quality in determining development and survival of Calanus pacificus (Copepoda: Calanoida). Mar Biol 95 $103-113$

Jacobson DM, Anderson DM (1996). Widespread phagocytosis of ciliates and other protists by marine mixotrophic and heterotrophic thecate dinoflagellates. J Phycol 32:279-285

Jeong HJ (1995) The interactions between microzooplanktonic grazers and dinoflagellates causing red tides in the open coastal waters off southern California. PhD thesis, University of California, San Diego

Jeong HJ (1996) The predation impact by heterotrophic dinoflagellate Protoperidinium cf. divergens on copepod eggs in the presence of co-occurring phytoplankton prey. J Kor Soc Oceanogr 31:144-149

Jeong HJ, Latz MI (1994) Growth and grazing rates of the heterotrophic dinoflagellates Protoperidinium spp. on redtide dinoflagellates. Mar Ecol Prog Ser 106:173-185

Jeong HJ, Lee CW, Yih WH, Kim JS (1997) Fragilidium of mexicanum, a thecate mixotrophic dinoflagellate, which is prey for and a predator on co-occurring thecate heterotrophic dinoflagellate Protoperidinium of. divergens. Mar Ecol Prog Ser 151:299-305

Jeong HJ, Shim JH, Lee CW, Kim JS, Koh SM (1999) Growth and grazing rates of the marine planktonic ciliate Strombidinopsis $\mathrm{sp}$. on red-tide and toxic dinoflagellates. J Euk Microb 46:69-76

Keller MD, Shapiro LP, Haugen EM, Cucci TL, Sherr EB, Sherr BF (1994) Phagotrophy of fluorescently labeled bacteria by an oceanic phytoplankter. Microb Ecol 28:39-52

Li A, Stoecker DK, Coats DW, Adam EJ (1996) Ingestion of fluorescently labeled and phycoerythrin-containing prey 
by mixotrophic dinoflagellates. Aquat Microb Ecol 10: $139-147$

Norris L. Chew KK (1975) Effects of environmental factors on growth of Gonyaulax catenalla. In: Locicero VR (ed) Proc 1st Int Conf Toxic Dinoflagellate Blooms. Massachusetts Science and Technology Foundation, Wakefield, p 143-152

Sanders RW, Porter KG, Caron DA (1990) Relationship between phototrophy and phagotrophy in the mixotrophic Chrysophyte Poterioochromonas malhamensis. Microb Ecol 19:97-109

Scura ED, Jerde C (1977) Various species of phytoplankton as food for larval northern anchovy, Engraulis mordax, and relative nutritional values of the dinoflagellate Gymnodinium splendens and Gonyaulax polyedra. Fish Bull 75: $577-583$

Skovgaard A (1996a) Engulfment of Ceratium spp. (Dinophyceae) by the thecate photosynthetic dinoflagellate Fragilidium subglobosum. Phycologia 35:490-499

Skovgaard A. (1996b) Mixotrophy in Fragilidium subglobo-

Editorial responsibility: Diane Stoecker (Contributing Editor), Cambridge, Maryland, USA sum (Dinophyceae): growth and grazing responses as functions of light intensity. Mar Ecol Prog Ser 143:247-253 Steidinger KA, Tangen K (1996) Dinoflagellates. In: Tomas $C R$ (ed) Identifying marine diatom and dinoflagellates. Academic Press, San Diego

Stoecker DK, Guillard RRL, Kavee RM (1981) Selective predation by Favella ehrenbergii (Tintinnida) on and among dinoflagellates. Biol Bull 160:136-145

Stoecker DK, Li A, Coats DW, Gustafson DE, Nannen MK (1997) Mixotrophy in the dinoflagellate Prorocentrum minimum. Mar Ecol Prog Ser 152:1-12

Strathmann RR (1967) Estimating the organic carbon content of phytoplankton from cell volume or plasma volume. Limnol Oceanogr 12:411-418

Watras CJ, Garcon VC, Olson RJ, Chisholm SW, Anderson DM (1985) The effect of zooplankton grazing on estuarine blooms of the toxic dinoflagellate Gonyaulax tamarensis. J Plankton Res 7:891-908

Zar JH (1984) Biostatistical analysis. Prentice Hall, Englewood Cliffs

Submitted: January 17, 1998; Accepted: September 28, 1998 Proofs received from author(s): January 11, 1999 